\title{
Bacteriophage application restores ethanol fermentation characteristics disrupted by Lactobacillus fermentum
}

\author{
Mei Liu', Kenneth M. Bischoff², Jason J. Gill ${ }^{3,4}$, Miranda D. Mire-Criscione1, Joel D. Berry ${ }^{3}$, Ry Young 3,5 \\ and Elizabeth J. Summer ${ }^{1 *}$
}

\begin{abstract}
Background: Contamination of corn mash by lactic acid bacteria (LAB) reduces the efficiency of the ethanol fermentation process. The industry relies heavily on antibiotics for contamination control and there is a need to develop alternative methods. The goals of this study were to determine the diversity and abundance of bacteria contaminating commercial ethanol fermentations, and to evaluate the potential of anti-LAB bacteriophages in controlling production losses.

Results: Bacterial populations in 27 corn mash samples collected from nine different commercial plants were determined by pyrosequencing of $16 \mathrm{~S}$ rRNA amplicons. The results showed that the most abundant bacteria ( $>50 \%$ of total population) in 24 of the 27 samples included LAB genera such as Lactobacillus, Streptococcus, Lactococcus, Weissella, Enterococcus, and Pediococcus. Lactobacillus was identified as the most prevalent genus at all fermentation stages in all plants, accounting for between 2.3 and $93.7 \%$ of each population and constituting the major genus (>50 \%) in nine samples from five plants and the most abundant genus in five other samples. Lactobacillus species, including $L$. delbrueckii, L. fermentum, L. mucosae, and L. reuteri were the most well-represented species. Two bacteriophages that target L. fermentum strains from ethanol plants, vB_LfeS_EcoSau and vB_LfeM_Ecolnf (EcoSau and Ecolnf), were isolated and characterized as a siphophage and a myophage, respectively. Analysis of the 31,703 bp genome of EcoSau revealed its similarity to the P335-like phage group, and the 106,701 bp genome of phage Ecolnf was determined to be a novel phage type despite its distant relationship to the SPO1-like phages. Addition of phages EcoSau and Ecolnf to $L$. fermentum-contaminated corn mash fermentation models restored the yields of ethanol and reduced levels of residual glucose, lactic acid, and acetic acid to that comparable to the infection-free control.
\end{abstract}

Conclusions: This study provides detailed insight into the microbiota contaminating commercial ethanol fermentations, and highlights the abundance of $\mathrm{LAB}$, especially L. delbrueckii, L. fermentum, L. mucosae, and L. reuteri, in the process. This study suggests that phages with broad coverage of major $L A B$ species can be applied directly to corn mash for antibiotic-free control of contamination in the ethanol fermentation industry.

Keywords: Lactic acid bacteria, Lactobacillus fermentum, Ethanol fermentation, Bacteriophage

\section{Background}

Commercial biofuel ethanol fermentation plants utilize starch or sugar as substrate and rely on yeast for fermentation. Biofuel ethanol fermentation is not a sterile

${ }^{*}$ Correspondence: liz@ecolyse.com

1 Ecolyse Inc., 11142 Hopes Creek Rd., College Station, TX 77845, USA

Full list of author information is available at the end of the article process: during normal operation, $10^{5}-10^{8}$ colony forming units (cfu) per milliliter of bacteria may be present in the system [1]. Lactic acid bacteria (LAB) are problematic for the industry not only through competition for the fermentation feedstock but also through the generation of lactic and acetic acid byproducts that inhibit yeast growth [2-6]. Even a single $\log ^{10}$ reduction in the amount of LAB can increase ethanol yield by approximately $3.7 \%$ 
[5]. Common approaches used by fermentation plants to reduce $L A B$ contamination include sanitization and the addition of antibiotics such as virginiamycin and penicillin [7]. However, none of the currently used approaches are perfect and fermentation plants continue to experience LAB-associated yield losses [1,7]. There is also increasing pressure to reduce the potential for antibiotic residues in the dried distillers' grains that are sold postprocess for animal feeds $[5,8]$. Therefore, there is a need to develop new control methods that are not based on chemical antibiotics. One such approach, evaluated here, is the use of bacteriophages.

The diversity of the contaminating LAB in biofuel ethanol fermentation has been analyzed extensively using culture-based approaches. The predominant group of bacteria isolated from corn-based ethanol fermentation facilities are reported to be LAB genera Lactobacillus, Bifidobacterium, Lactococcus, Leuconostoc, Pediococcus, and Weisella $[1,9]$. The LAB species most frequently isolated from fermentation vessels are Lactobacillus species, including L. fermentum, L. vini, L. johnsonii, L. mucosae and $L$. amylovorus $[1,7,8]$. However, culture-based approaches are subject to well-known limitations and broad, culture-independent surveys of bacterial diversity at commercial corn ethanol fermentation facilities are not available. Similarly, LAB phages are among the most extensively catalogued of all phages, primarily due to their well-documented detrimental impact on food fermentation processes [10-12]. Over 1000 phages of Lactococcus and Streptococcus alone have been described at least to the level of virus particle morphology [13]. Phages infecting dairy strains of Lactococcus lactis and Streptococcus thermophilus have been the focus of considerable analysis, with 66 and 11 complete genome sequences available, respectively $[11,14]$. However, phages capable of broadly controlling the LAB populations present specifically in ethanol fermentation facilities have not been described.

Phage-based antibacterial agents have been evaluated in various medical, agricultural, and industrial settings $[6,15-18]$. The use of phage is complicated by the tendency for most phage to infect an extremely limited number of host strains, frequently only one or a few strains of a given species. Therefore, developing a phagebased product necessitates a detailed understanding of the real diversity present in the targeted system in order to ensure the inclusion of phages with sufficient host coverage. Additionally, phage efficacy testing needs to include all components present in the industrial process. Fully developing a phage preparation that can be used in commercial fermentation plants requires isolation of phages that show killing activity against the same diversity of LAB strains present in commercial plants, as well as demonstration of phage killing activity in a corn mash matrix. Previous studies demonstrated that phages were capable of controlling L. plantarum ATCC 8014 when co-cultured with yeast in defined liquid culture media [19]. Purified phage lytic enzymes were shown to be able to lyse Lactobacillus strains in both culture media and in mock fermentations using corn fiber hydrolysates as substrates [20]. In addition, expression of phage lytic enzymes in yeast reduced $L$. fermentum, as well as lactic acid and acetic acid levels during corn mash fermentations [21]. In the research presented here, bacterial diversity was analyzed in commercial corn mash samples and phages capable of killing the predominant LAB strains were isolated and tested for their effects on the end fermentation products in a corn mash fermentation assay.

\section{Results}

Bacterial population analysis in commercial corn mash during early, middle, late stage fermentation

Between July 2011 and August 2012, samples were collected from nine different commercial corn ethanol fermentation plants (Table 1). Samples were collected from fermentors during early, middle, and late fermentation stages, all $\mathrm{pH} \sim 4-4.5$ and containing yeast at $8 \times 10^{7}-2 \times 10^{8} \mathrm{cfu} / \mathrm{g}$. Culturable bacterial counts were found to vary greatly, ranging from $10^{3}$ to $10^{7} \mathrm{cfu} / \mathrm{g}$. There was no direct correlation between the total bacterial counts and the stage of the fermentation (Table 1).

Bacterial population analysis was conducted by $16 \mathrm{~S}$ amplicon pyrosequencing. Between 2124 and 27,188 (average of 5025) 16S sequences were generated from each sample (Table 1). A significant proportion of these were identified as probably plastid in origin and excluded from subsequent population analysis. The sequences were clustered into operational taxonomic units (OTU) at $1 \%$ divergence, between 7 and 98 per sample, for a total of 243 OTU in all 27 samples (Table 1). Of the 243 OTU, 51 belonged to members of the LAB. LAB-derived sequences were overall the most common, from 36.1 to $99.9 \%$, in every sample, and were the most abundant ( $>50 \%$ of total population) in 24 of the 27 samples (Table 1). LAB genera present in the samples included Lactobacillus, Streptococcus, Lactococcus, Weissella, Enterococcus and Pediococcus. Of these, Lactobacillus was the most widespread genus, with representatives identified in all 27 samples from all nine fermentation facilities at $2.3-93.7 \%$ of the population and constituting the major genus $(>50 \%)$ in nine samples from five plants and the most abundant genus in five other samples. Streptococcus, Lactococcus and Weisella species were also well represented, being found in 20, 15 and 12 samples, respectively, but were the majority in fewer samples (two, four and five, respectively). The less widely distributed 
Table 1 Bacterial population diversity at early, mid, and late fermentation stages in nine different commercial ethanol plants

\begin{tabular}{|c|c|c|c|c|c|c|c|c|c|c|c|}
\hline Plant & $\begin{array}{l}\text { Fermenta- } \\
\text { tion stage } \\
\text { (hours) }\end{array}$ & $\begin{array}{l}\text { Bacteria } \\
\text { level } \\
\text { (CFU/g) }\end{array}$ & $\begin{array}{l}\text { \# of total } \\
\text { OTU }\end{array}$ & $\begin{array}{l}\text { \# of LAB } \\
\text { OTU }\end{array}$ & $\begin{array}{l}\text { Lactoba- } \\
\text { cillus (\%) }\end{array}$ & $\begin{array}{l}\text { Strepto- } \\
\text { coccus (\%) }\end{array}$ & $\begin{array}{l}\text { Lactococ- } \\
\text { cus (\%) }\end{array}$ & $\begin{array}{l}\text { Weissella } \\
\text { (\%) }\end{array}$ & $\begin{array}{l}\text { Enterococ- } \\
\text { cus }(\%)\end{array}$ & $\begin{array}{l}\text { Pediococ- } \\
\text { cus (\%) }\end{array}$ & $\begin{array}{l}\text { Total LAB } \\
(\%)^{\mathrm{a}}\end{array}$ \\
\hline \multirow[t]{3}{*}{1} & 11 & NA & 68 & 7 & 36.10 & & & & & & 36.10 \\
\hline & 24 & NA & 98 & 12 & 91.91 & 0.02 & & & 0.01 & & 91.94 \\
\hline & 52 & NA & 21 & 6 & 91.09 & 0.78 & & & & & 91.87 \\
\hline \multirow[t]{3}{*}{2} & 25 & $4.4 \mathrm{E}+07$ & 16 & 10 & 5.78 & 0.51 & 0.65 & 92.22 & 0.07 & & 99.23 \\
\hline & 34 & $1.9 \mathrm{E}+07$ & 15 & 10 & 3.62 & 0.61 & 0.47 & 79.50 & & 0.10 & 84.30 \\
\hline & 43 & $9.4 \mathrm{E}+06$ & 15 & 12 & 16.09 & 9.98 & 3.42 & 70.10 & & & 99.59 \\
\hline \multirow[t]{3}{*}{3} & 15 & $8.6 \mathrm{E}+04$ & 30 & 21 & 4.53 & 0.18 & 63.08 & 30.34 & 0.02 & & 98.15 \\
\hline & 30 & $3.6 \mathrm{E}+04$ & 19 & 10 & 47.36 & 0.35 & 0.35 & 39.58 & & & 87.64 \\
\hline & 45 & $1.7 \mathrm{E}+04$ & 24 & 9 & 16.54 & & 0.44 & 75.51 & & & 92.49 \\
\hline \multirow[t]{3}{*}{4} & 9 & $1.6 \mathrm{E}+07$ & 55 & 15 & 7.32 & 4.93 & 0.66 & 11.86 & & & 24.77 \\
\hline & 27 & $1.8 \mathrm{E}+06$ & 19 & 13 & 54.70 & 25.07 & 0.33 & 18.47 & & & 98.57 \\
\hline & 45 & $7.8 \mathrm{E}+04$ & 17 & 11 & 82.66 & 8.92 & 1.48 & 5.85 & & & 98.91 \\
\hline \multirow[t]{3}{*}{5} & 18 & $1.2 \mathrm{E}+07$ & 11 & 8 & 40.64 & & 58.42 & 0.64 & 0.07 & & 99.77 \\
\hline & 32 & $1.8 \mathrm{E}+06$ & 18 & 9 & 75.00 & & 23.51 & 0.06 & & & 98.57 \\
\hline & 45 & $8.6 \mathrm{E}+05$ & 14 & 5 & 70.55 & & 2.47 & & 25.60 & & 98.62 \\
\hline \multirow[t]{3}{*}{6} & 8 & $5.6 \mathrm{E}+05$ & 18 & 17 & 28.56 & 69.03 & & & 0.75 & & 98.34 \\
\hline & 26 & $2.5 \mathrm{E}+05$ & 26 & 18 & 81.77 & 8.84 & & & 5.11 & 0.41 & 96.13 \\
\hline & 34 & $1.0 \mathrm{E}+07$ & 12 & 11 & 93.71 & 6.18 & & & & & 99.89 \\
\hline \multirow[t]{3}{*}{7} & 15 & $4.4 \mathrm{E}+03$ & 25 & 7 & 13.15 & 4.21 & 46.31 & & 0.52 & 3.16 & 67.35 \\
\hline & 34 & $2.8 \mathrm{E}+05$ & 41 & 9 & 39.46 & 5.54 & 5.54 & & & & 50.54 \\
\hline & 42 & $2.8 \mathrm{E}+04$ & 18 & 6 & 17.61 & 1.14 & 68.47 & & & & 87.22 \\
\hline \multirow[t]{3}{*}{8} & 17 & $2.2 \mathrm{E}+06$ & 7 & 7 & 2.31 & 97.54 & & & & & 99.85 \\
\hline & 35 & $7.8 \mathrm{E}+05$ & 8 & 5 & 67.46 & 22.81 & & & 9.20 & & 99.47 \\
\hline & 54 & $7.0 \mathrm{E}+03$ & 14 & 9 & 38.86 & 23.45 & & & 36.40 & & 98.71 \\
\hline \multirow[t]{3}{*}{9} & 6 & $3.0 \mathrm{E}+05$ & 23 & 8 & 14.20 & & & 0.71 & & 41.84 & 56.75 \\
\hline & 24 & $2.5 \mathrm{E}+05$ & 19 & 7 & 26.94 & 0.52 & & & & 54.92 & 82.38 \\
\hline & 49 & $3.0 \mathrm{E}+04$ & 32 & 6 & 29.34 & & & & & 14.97 & 44.31 \\
\hline
\end{tabular}

Values less than $0.01 \%$ or not detected are not shown

OTU operational taxonomic units, NA data not available

a $\%$ of LAB is calculated as the sum at Lactobacillales order level

genera were not necessarily the least abundant genera. For example, while Pediococcus species were present in only six samples, Pediococcus was the most abundant bacterial genus in one plant (Plant 9), accounting for 41.8, 54.9 , and $15.0 \%$ of the total bacteria in early, mid, late stage fermentation, respectively (Table 1 ).

The average abundance of each bacterial genus, calculated using only the samples in which each genus was present, varied depending on the stage of fermentation (Fig. 1). While overall LAB levels increased from early to late stage fermentation, from 75.6 to $90.2 \%$, the increase was not observed across all genera. Lactobacillus, Weissella, and Enterococcus levels were significantly higher at late stage as compared to early stage fermentation. In contrast, Streptococcus, Lactococcus and Pediococcus levels were reduced in late stage fermentation samples as compared to the early stage fermentation samples (Fig. 1). It should be noted that not every sample contained every genus so the data set is more robust for Lactobacillus and Streptococcus than for organisms present in fewer samples. When the sample distribution of different species was analyzed, several particularly predominant LAB species (defined as being present at $\geq 20 \%$ of total population in any sample tested) were identified (Table 2). These notable species included Enterococcus faecium, Lactobacillus delbrueckii, L. fermentum, L. mucosae, L. reuteri, Lactococcus lactis, Pediococcus pentosaceus, and Weissella confusa, and their relative abundance varied from sample to sample (Table 2).

The patterns of abundance and distribution of non-LAB OTU were quite different from that of the LAB. While 192 non-LAB OTU were identified, the distribution 


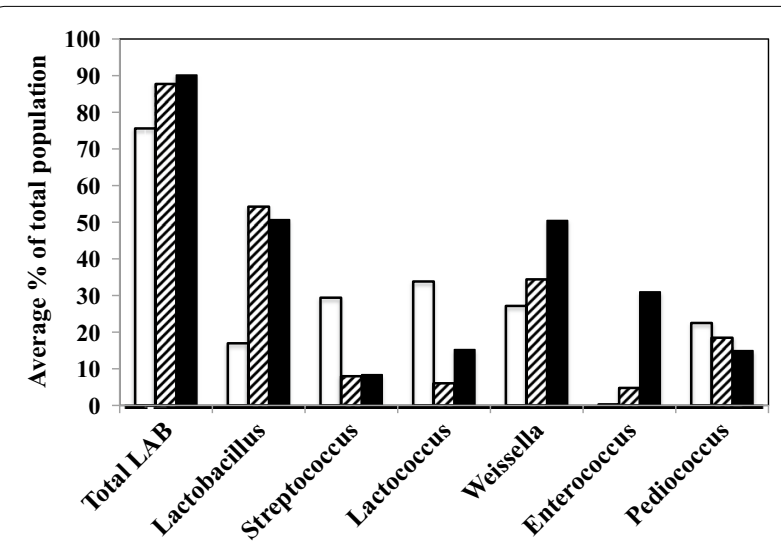

Fig. 1 Average percentages of total $L A B$ and different $L A B$ genera at different fermentation stages. Early (empty bar), mid (striped bar), and late (filled bar) fermentation samples are presented. Values were calculated using only samples in which those populations were present among the samples was uneven-ranging from just one to 86 different OTU per sample. The average number of non-LAB OTU in each sample was $15( \pm 19.5)$ while the average number of LAB OTU in each sample was 10 $( \pm 4.0)$. In order to represent the number of shared species between each sample, the Sørensen-Dice index was calculated for each pairwise comparison (Table 3). This calculation presents the shared OTU as a function of potentially shared OTU, generating a value between 0 (no shared OTU) and 1 (100\% shared OTU, which is the value obtained when a sample is compared to itself). Values closer to 1 indicate a greater proportion of the potentially shared OTU is present in both samples.

The pairwise comparisons were generated between every sample for both LAB and non-LAB genera (Table 3). Several patterns emerged from this analysis. First, the LAB populations were more uniform across samples

Table 2 Predominant bacterial species of nine different commercial ethanol plants

\begin{tabular}{|c|c|c|c|c|c|c|c|c|c|}
\hline Plant & $\begin{array}{l}\text { Fermenta- } \\
\text { tion stage } \\
\text { (hours) }\end{array}$ & $\begin{array}{l}\text { Enterococcus } \\
\text { faecium (\%) }\end{array}$ & $\begin{array}{l}\text { Lactobacillus } \\
\text { delbrueckii } \\
(\%)\end{array}$ & $\begin{array}{l}\text { Lactobacillus } \\
\text { fermentum } \\
(\%)\end{array}$ & $\begin{array}{l}\text { Lactobacillus } \\
\text { mucosae (\%) }\end{array}$ & $\begin{array}{l}\text { Lactobacil- } \\
\text { lus reuteri } \\
\text { (\%) }\end{array}$ & $\begin{array}{l}\text { Lactococcus } \\
\text { lactis (\%) }\end{array}$ & $\begin{array}{l}\text { Pediococcus } \\
\text { pentosaceus } \\
(\%)\end{array}$ & $\begin{array}{l}\text { Weissella } \\
\text { confusa (\%) }\end{array}$ \\
\hline \multirow[t]{3}{*}{1} & 11 & & & 0.3 & 9.5 & 6.1 & & & \\
\hline & 24 & & 0.8 & 1.2 & 42.5 & 29.5 & & & \\
\hline & 52 & & & 42.4 & & 32.6 & & & \\
\hline \multirow[t]{3}{*}{2} & 25 & & & 4.7 & 0.4 & & & & 48.2 \\
\hline & 34 & & & 3.2 & 0.3 & & & 0.1 & 46.9 \\
\hline & 43 & & & 11.8 & 0.4 & & & & 44.7 \\
\hline \multirow[t]{3}{*}{3} & 15 & & 2.3 & 0.4 & 0.7 & & 36.7 & & 16.3 \\
\hline & 30 & & 31.3 & 13.7 & 0.2 & & 0.4 & & 21.8 \\
\hline & 45 & & 11.9 & 1.8 & & & & & 67.3 \\
\hline \multirow[t]{3}{*}{4} & 9 & & 11.3 & 5.3 & 9.6 & & 0.9 & & 33.2 \\
\hline & 27 & & 26.5 & 0.9 & 15.1 & & 0.9 & & 14.6 \\
\hline & 45 & & 45.9 & 3.2 & 18.8 & & & & 5.8 \\
\hline \multirow[t]{3}{*}{5} & 18 & & 0.5 & 0.6 & 5.0 & & 34.0 & & 0.4 \\
\hline & 32 & & 4.1 & 1.4 & 67.8 & & 14.1 & & 0.5 \\
\hline & 45 & & 4.9 & & 65.2 & & 0.9 & & \\
\hline \multirow[t]{3}{*}{6} & 8 & 2.3 & 0.4 & 0.2 & 4.9 & 1.5 & & & \\
\hline & 26 & 4.9 & 0.7 & 0.6 & 35.5 & 15.8 & & 0.2 & \\
\hline & 34 & 0.3 & & 0.4 & 9.9 & 1.4 & & & \\
\hline \multirow[t]{3}{*}{7} & 15 & & & 4.7 & 0.7 & 2.3 & 28.2 & 2.3 & \\
\hline & 34 & & 0.2 & 29.7 & 3.5 & 0.7 & 3.4 & & \\
\hline & 42 & & 2.1 & 0.7 & 15.7 & 0.2 & 37.0 & & \\
\hline \multirow[t]{3}{*}{8} & 17 & & & 1.2 & 0.3 & & & & \\
\hline & 35 & 8.9 & & 54.1 & 11.3 & & & & \\
\hline & 54 & 36.4 & & 28.7 & 6.3 & & & & \\
\hline \multirow[t]{3}{*}{9} & 6 & & & 1.4 & 8.5 & 0.3 & & 44.3 & \\
\hline & 24 & & 0.3 & 1.9 & 9.3 & & & 54.2 & 0.3 \\
\hline & 49 & & & 0.5 & 15.5 & 0.2 & & 13.5 & \\
\hline
\end{tabular}

Predominant species are defined as those present at $\geq 20 \%$ of total bacterial population (italic numbers) in any sample. Values not detected or less than $0.1 \%$ are not shown 
Table 3 Pair-wise comparison of LAB and non-LAB shared species among early, mid, and late fermentation samples of nine plants

\begin{tabular}{|c|c|c|c|c|c|c|c|c|c|c|c|c|c|c|c|c|c|c|c|c|c|c|c|c|c|c|c|}
\hline $\mathrm{A}$ & $1 \mathrm{E}$ & $1 \mathrm{M}$ & $1 \mathrm{~L}$ & $2 \mathrm{E}$ & $2 \mathrm{M}$ & $2 \mathrm{~L}$ & $3 \mathrm{E}$ & $3 \mathrm{M}$ & $3 \mathrm{~L}$ & $4 \mathrm{E}$ & $4 \mathrm{M}$ & $4 \mathrm{~L}$ & $5 \mathrm{E}$ & $5 \mathrm{M}$ & $5 \mathrm{~L}$ & $6 \mathrm{E}$ & $6 \mathrm{M}$ & $6 \mathrm{~L}$ & $7 E$ & $7 \mathrm{M}$ & $7 \mathrm{~L}$ & $8 \mathrm{E}$ & $8 \mathrm{M}$ & $8 \mathrm{~L}$ & $9 \mathrm{E}$ & $9 \mathrm{M}$ & 9L \\
\hline $1 E$ & 1 & 0.6 & 0.2 & 0.1 & 0 & 0.1 & 0 & 0.1 & 0.2 & 0.3 & 0 & 0 & 0 & 0.1 & 0.1 & 0 & 0.1 & 0 & 0.1 & 0.2 & 0.1 & 0 & 0.1 & 0.1 & 0.1 & 0.1 & 0.2 \\
\hline $1 \mathrm{M}$ & 0.7 & 1 & 0.2 & 0.1 & 0 & 0 & 0 & 0 & 0.1 & 0.2 & 0.1 & 0 & 0 & 0.1 & 0.1 & 0 & 0 & 0 & 0.1 & 0.1 & 0.1 & 0 & 0 & 0.1 & 0.1 & 0 & 0.1 \\
\hline $1 \mathrm{~L}$ & 0.6 & 0.4 & 1 & 0.1 & 0 & 0.1 & 0 & 0.1 & 0.2 & 0.2 & 0.2 & 0.1 & 0.1 & 0.1 & 0.2 & 0 & 0.1 & 0.1 & 0 & 0 & 0 & 0 & 0.1 & 이 & 0 & 0 & $c$ \\
\hline $2 \mathrm{E}$ & 0.4 & 0.4 & 0.3 & 1 & 0 & 0.2 & 0 & 0.1 & 0 & 0.1 & 0 & 0 & 0.2 & 0.1 & 0.1 & 0 & 0.1 & 0.3 & 0 & 0.1 & ( & 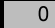 & 0.2 & 0 & 0.1 & 0 & c \\
\hline $2 \mathrm{M}$ & 0.4 & 0.4 & 0.3 & 0.8 & 1 & 0 & 0 & 0 & 0 & 0 & 0 & 0 & 0 & 0.1 & 0.1 & 0 & 0 & 0 & 0.1 & 0.1 & 0.1 & 0 & 0 & 0.2 & 0.1 & 0.1 & 0.1 \\
\hline $2 \mathrm{~L}$ & .3 & 0.3 & 0.3 & 0.7 & 0.7 & 1 & 0 & 0 & 0.1 & 0.1 & 0 & 0 & 0.3 & 0.1 & 0.1 & 0 & 0.2 & 0.3 & 0 & 0.1 & 0.1 & 0 & 0.3 & 0 & 0 & 0 & c \\
\hline $3 \mathrm{E}$ & 0.3 & 0.4 & 0.2 & 0.5 & 0.5 & 0.5 & 1 & 0.1 & 0.3 & 0 & 0.1 & 0 & 0 & 0 & 0 & 0 & 0.2 & 0 & 0.1 & 0 & 0.1 & 0 & 0 & 이 & 0.2 & 0.2 & 0.1 \\
\hline $3 M$ & 0.2 & 0.4 & 0.3 & 0.5 & 0.5 & 0.5 & 0.6 & 1 & 0.3 & 0.1 & 0.1 & 0.3 & 0 & 0 & 0.2 & 0 & 0.2 & 0 & 0.1 & 0.1 & 0.2 & 0 & 0 & 이 & 0.2 & 0.3 & 0.2 \\
\hline $3 \mathrm{~L}$ & 0.3 & 0.3 & 0.3 & 0.5 & 0.5 & 0.5 & 0.6 & 0.8 & 1 & 0.3 & 0.2 & 0.1 & 0 & 0 & 0.1 & 0 & 0.1 & 0 & 0.1 & 0.1 & 0 & 0 & 0 & 0.1 & 0.1 & 0.2 & 0.2 \\
\hline $4 \mathrm{E}$ & .3 & 0.4 & 0.2 & 0.6 & 0.6 & 0.5 & 0.5 & 0.6 & 0.5 & 1 & 0.1 & 0 & 0.1 & 0.2 & 0.2 & 0 & 0 & 0 & 0.2 & 0.4 & 0.2 & & 0.1 & 0.2 & 0.1 & 0.2 & 0.3 \\
\hline $\mathrm{M}$ & .4 & 0.5 & 0.3 & 0.6 & 0.6 & 0.6 & 0.7 & 0.6 & 0.5 & 0.7 & 1 & 0 & 0 & 0 & 0.1 & 0 & 0 & 0 & 0.2 & 0.1 & 0.2 & 0 & 0.2 & 0 & 0.2 & 0.1 & 0.1 \\
\hline $4 \mathrm{~L}$ & 0.3 & 0.4 & 0.4 & 0.6 & 0.6 & 0.5 & 0.6 & 0.6 & 0.5 & 0.7 & 0.8 & 1 & 0 & 0 & 0.4 & 0 & 0.3 & 0 & 0.2 & 0.1 & 0.2 & 0 & 0 & 이 & 0.1 & 0.2 & 0.2 \\
\hline $5 \mathrm{E}$ & 0.3 & 0.3 & 0.1 & 0.4 & 0.4 & 0.4 & 0.5 & 0.6 & 0.6 & 0.5 & 0.6 & 0.6 & 1 & 0.3 & 0.3 & 0 & 0.2 & 0.5 & 0.1 & 0.1 & 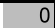 & 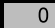 & 0.3 & 0 & 0.1 & 0 & 0.1 \\
\hline $5 \mathrm{M}$ & 0.3 & 0.3 & 0.3 & 0.4 & 0.4 & 0.4 & 0.5 & 0.4 & 0.4 & 0.5 & 0.6 & 0.7 & 0.7 & 1 & 0.3 & 0 & 0.1 & 0.2 & 0.1 & 0.1 & 0.2 & ( & 0.3 & 0.4 & 0.2 & 0.1 & 0.2 \\
\hline $5 \mathrm{~L}$ & 0.2 & 0.2 & 0.2 & 0.3 & 0.1 & 0.1 & 0.3 & 0.3 & 0.3 & 0.3 & 0.4 & 0.5 & 0.5 & 0.6 & 1 & 0 & 0.4 & 0.2 & 0.4 & 0.2 & 0.4 & u & 0.2 & 0.1 & 0.4 & 0.3 & 0.3 \\
\hline $6 \mathrm{E}$ & 0.3 & 0.5 & 0.3 & 0.3 & 0.3 & 0.3 & 0.3 & 0.3 & 0.2 & 0.6 & 0.4 & 0.5 & 0.2 & 0.2 & 0.2 & 1 & 0 & 0 & 0 & 0.1 & 0 & 0 & 0 & 0 & 0 & 0 & c \\
\hline $6 \mathrm{M}$ & 0.3 & 0.5 & 0.3 & 0.3 & 0.4 & 0.3 & 0.4 & 0.3 & 0.2 & 0.5 & 0.4 & 0.5 & 0.2 & 0.3 & 0.3 & 0.8 & 1 & 0.2 & 0.3 & 0.2 & 0.3 & 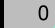 & 0.2 & 이 & 0.1 & 0.5 & 0.3 \\
\hline $6 \mathrm{~L}$ & 0.4 & 0.4 & 0.5 & 0.4 & 0.4 & 0.3 & 0.4 & 0.3 & 0.2 & 0.5 & 0.5 & 0.5 & 0.2 & 0.3 & 0.3 & 0.7 & 0.7 & 1 & 0 & 0 & 0 & 0 & 0.5 & 0 & 0 & 0 & c \\
\hline $7 \mathrm{E}$ & 0.3 & 0.3 & 0.5 & 0.2 & 0.4 & 0.2 & 0.3 & 0.4 & 0.3 & 0.3 & 0.4 & 0.4 & 0.4 & 0.4 & 0.3 & 0.3 & 0.4 & 0.4 & 1 & 0.5 & 0.5 & ( & 0.1 & 0.2 & 0.4 & 0.5 & 0.5 \\
\hline $7 \mathrm{M}$ & 0.5 & 0.6 & 0.5 & 0.4 & 0.4 & 0.4 & 0.5 & 0.5 & 0.4 & 0.6 & 0.6 & 0.7 & 0.5 & 0.6 & 0.6 & 0.5 & 0.6 & 0.7 & 0.6 & 1 & 0.4 & 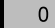 & 0.1 & 0.2 & 0.3 & 0.2 & 0.3 \\
\hline 7L & 0.3 & 0.4 & 0.2 & 0.4 & 0.4 & 0.4 & 0.4 & 0.5 & 0.4 & 0.5 & 0.5 & 0.6 & 0.6 & 0.5 & 0.5 & 0.3 & 0.3 & 0.4 & 0.5 & 0.7 & 1 & 0 & 0.3 & 0.3 & 0.4 & 0.5 & 0.5 \\
\hline $8 \mathrm{E}$ & 0.4 & 0.4 & 0.2 & 0.4 & 0.4 & 0.3 & 0.3 & 0.2 & 0.1 & 0.4 & 0.4 & 0.3 & 0.3 & 0.3 & 0.2 & 0.4 & 0.4 & 0.4 & 0.3 & 0.5 & 0.5 & 1 & 0 & 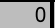 & 0 & 0 & c \\
\hline $8 \mathrm{M}$ & 0.3 & 0.4 & 0.2 & 0.4 & 0.4 & 0.4 & 0.2 & 0.3 & 0.1 & 0.3 & 0.3 & 0.4 & 0.3 & 0.3 & 0.2 & 0.5 & 0.4 & 0.4 & 0.3 & 0.4 & 0.5 & 0.7 & 1 & 0.3 & 0.1 & 0.1 & 0.1 \\
\hline $8 \mathrm{~L}$ & 0.3 & 0.4 & 0.1 & 0.3 & 0.3 & 0.3 & 0.2 & 0.2 & 0.1 & 0.3 & 0.3 & 0.4 & 0.2 & 0.2 & 0.1 & 0.5 & 0.4 & 0.3 & 0.3 & 0.3 & 0.4 & 0.5 & 0.7 & 1 & 0.1 & 0.1 & 0.2 \\
\hline $9 \mathrm{E}$ & 0.4 & 0.4 & 0.4 & 0.3 & 0.4 & 0.3 & 0.3 & 0.2 & 0.2 & 0.3 & 0.4 & 0.4 & 0.3 & 0.4 & 0.3 & 0.4 & 0.5 & 0.5 & 0.5 & 0.5 & 0.3 & 0.3 & 0.3 & 0.2 & 1 & 0.4 & 0.4 \\
\hline $9 \mathrm{M}$ & 0.3 & 0.3 & 0.3 & 0.4 & 0.5 & 0.3 & 0.3 & 0.2 & 0.1 & 0.5 & 0.5 & 0.6 & 0.3 & 0.4 & 0.3 & 0.4 & 0.5 & 0.7 & 0.6 & 0.5 & 0.5 & 0.4 & 0.5 & 0.4 & 0.7 & 1 & 0.6 \\
\hline 9L & 0.3 & 0.2 & 0.3 & 0.3 & 0.4 & 0.2 & 0.2 & 0.1 & 0.1 & 0.4 & 0.4 & 0.5 & 0.3 & 0.4 & 0.4 & 0.3 & 0.4 & 0.6 & 0.5 & 0.4 & 0.3 & 0.3 & 0.4 & 0.3 & 0.7 & 0.9 & 1 \\
\hline
\end{tabular}

Sørensen-Dice index values were presented and color-coded: gray (no species in common), white (up to 0.4), green (greater than 0.4), yellow (all species shared between the two samples). Values above the yellow diagonal are comparisons of non-LAB, values below yellow diagonal are comparisons of $L A B$

than the non-LAB populations. The average index calculated for $\mathrm{LAB}$ was $0.401 \pm 0.147$ and for non-LAB was $0.113 \pm 0.129$. These values indicate that despite the fact that many more types of non-LAB bacteria were identified in the 27 samples, each type was present in fewer samples. Many of the non-LAB pairwise comparisons were zero, indicating that the non- $\mathrm{LAB}$ component of most samples was completely unlike that of other sample. In contrast, distribution of LAB was more uniform as all samples contained at least one $\mathrm{LAB}$ in common with every other sample (Table 3).

In several samples, the non-LAB genera identified included organisms known to be problematic in other industrial settings, due to their corrosion, fouling or

Table 4 Non-LAB genera in commercial ethanol plants

\begin{tabular}{|c|c|c|c|}
\hline Metabolic trait & OTU & Samples & Example genera \\
\hline Sulfidogen, all & 22 & 15 & $\begin{array}{l}\text { Desulfovibrio, Dethiosulfo- } \\
\text { vibrio }\end{array}$ \\
\hline $\begin{array}{l}\text { Sulfate reducing } \\
\text { bacteria }\end{array}$ & 12 & 8 & Desulfotomaculum \\
\hline Other sulfidogens & 10 & 12 & Citrobacter \\
\hline Iron reducing bacteria & 7 & 10 & Shewanella, Geobacter \\
\hline $\begin{array}{l}\text { Acid producing bacteria, } \\
\text { alla }\end{array}$ & 59 & 27 & Alicyclobacillus \\
\hline Acetogen & 3 & 7 & Acetobacterium \\
\hline
\end{tabular}

OTU operational taxonomic units

a Acid producing bacteria include lactic acid bacteria sulfidogenic capacity (Table 4). Notable genera included acetogenic bacteria such as Acetobacterium, present in seven out of the 27 samples. Acetobacterium species are acid producing that ferment alcohols into acetic acid. Iron-reducing bacterial genera, including Shewanella and Geobacter, were present in ten of the 27 samples. Sulfidogenic bacteria, capable of evolving hydrogen sulfide, were present in 15 of the 27 samples. These sulfidogens included sulfate reducing bacteria (SRB) such as Desulfovibrio and Desulfotomaculum, as well as non-SRB sulfidogens such as Citrobacter. The samples with the greatest diversity of non-LAB populations (Plants 1 and 4, with 61 and 86 nonLAB genera, respectively) contained numerous isolates of sulfidogenic bacteria and iron-reducing bacteria. Interestingly, these organisms were present primarily in the early and mid-stage fermentation samples.

\section{Isolation of bacterial strains from commercial ethanol plants}

Corn mash samples were serial diluted and from the highest dilution plates, bacterial colonies representing dominant colony morphological types were isolated. These dominant isolates, both numerically and morphologically, were identified by sequencing of $16 \mathrm{~S}$ amplicons. The isolated strains included multiple representatives of 36 species from the LAB genera including Enterococcus, Lactobacillus, Lactococcus, Leuconostic, Pediococcus, Streptococcus, and Weissella. The identities of the ethanol plant isolates are consistent with the bacterial diversity 
survey. These LAB isolates were used as hosts for phage isolation and characterization.

\section{Isolation and characterization of $L$. fermentum phages EcoSau and Ecolnf}

Bacteriophages showing killing activity against fermentation plant $\mathrm{LAB}$ were isolated. Two of these, phages $\mathrm{vB}_{-}$ LfeS_EcoSau and vB_LfeM_EcoInf, were isolated from commercial sauerkraut and municipal wastewater influent water, respectively, using host L. fermentum 031525. L. fermentum 0315-25 was isolated from commercial corn mash and shown to be capable of reducing ethanol yields in an infected fermentation assay $[5,8]$. These two phages are hereafter referred to as EcoSau and EcoInf, respectively. The host ranges of EcoSau and EcoInf were assessed against $L$. fermentum and $L$. mucosae isolated from different commercial ethanol plants. EcoInf was active against all $12 \mathrm{~L}$. fermentum strains tested (representing eight plants) and one L. mucosae strain. EcoSau was active against ten $L$. fermentum strains (representing six plants) and two L. mucosae strains from one plant (Table 5).
The morphologies of phages EcoSau and EcoInf were determined by TEM (Fig. 2; Table 6). EcoSau virions consisted of long $(\sim 179 \mathrm{~nm})$ flexible, non-contractile tails with an average width of $\sim 10 \mathrm{~nm}$, and isometric capsids with an average diameter of $\sim 62 \mathrm{~nm}$, suggesting a $T=7$ icosahedral symmetry as seen in many siphophages, including the well-studied phages lambda and T1. EcoInf virions exhibited thick $(20 \mathrm{~nm})$, non-flexible, contractile tales of $\sim 202 \mathrm{~nm}$ and isometric heads with an average diameter of $\sim 89 \mathrm{~nm}$, typical of SPO1-like phages [22]. Morphologically, EcoSau and EcoInf were categorized as siphophage and myophage, respectively.

\section{Genomic analysis of phages EcoSau and Ecolnf}

Phages EcoInf and EcoSau were further characterized by whole genome sequencing (Table 6). Functional clusters encoding virion morphogenesis, DNA metabolism, and host cell lysis could be identified in both phages (Fig. 3). Annotation tables for phages EcoSau and EcoInf are shown in Additional files 1, 2: Tables S1, S2, respectively. The EcoSau genome was determined to be 31,703 bp and predicted to contain 50 protein-coding genes and no tRNA genes. The EcoSau genome produced a circular

Table 5 Activities of EcoSau and Ecolnf against $L$. fermentum and $L$. mucosae isolates

\begin{tabular}{|c|c|c|c|c|c|c|}
\hline & \multirow[t]{2}{*}{ Strains tested } & \multirow[t]{2}{*}{ Plants represented } & \multicolumn{2}{|c|}{ Susceptible to EcoSau ${ }^{a}$} & \multicolumn{2}{|c|}{ Susceptible to Ecolnf ${ }^{a}$} \\
\hline & & & Strains & Plants & Strains & Plants \\
\hline L. fermentum & 12 & 8 & 10 & 6 & 12 & 8 \\
\hline L. mucosae & 8 & 4 & 2 & 1 & 1 & 1 \\
\hline
\end{tabular}

a Susceptibility assayed by spotting $10 \mu \mathrm{l}$ of a routine test dilution of phage ( $105 \mathrm{pfu} / \mathrm{ml})$
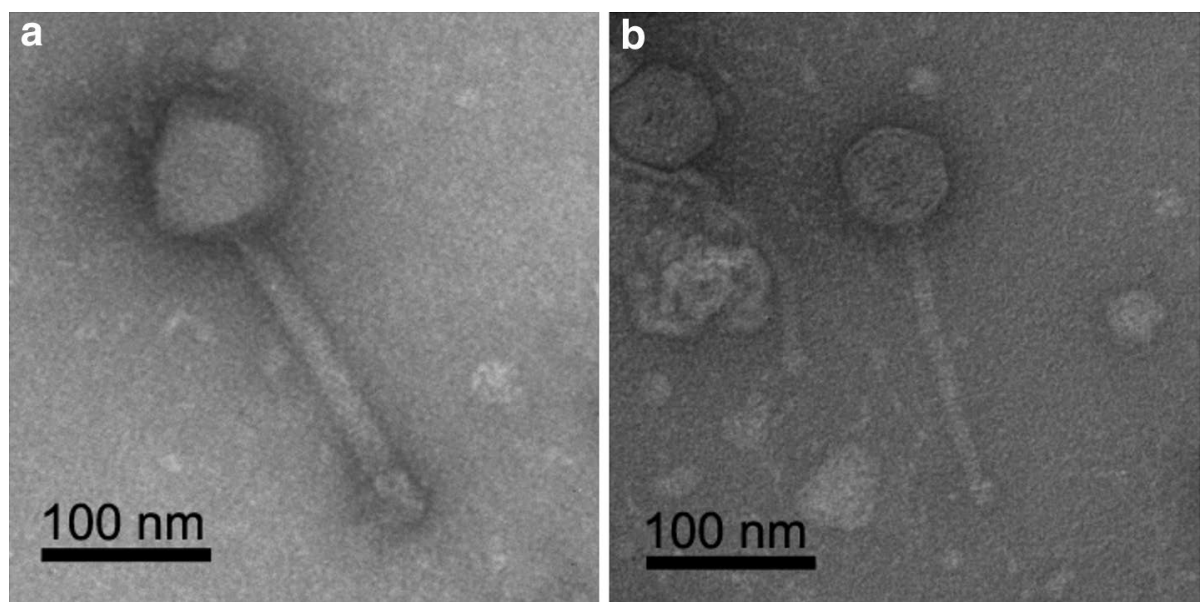

Fig. 2 Transmission electron micrographs of phages Ecolnf (a) and EcoSau (b). Bars $100 \mathrm{~nm}$ 
Table 6 Summary of the characteristics of phages EcoSau and Ecolnf

\begin{tabular}{|c|c|c|c|c|c|c|c|c|c|c|}
\hline Phage & Morphology & Phage group & $\begin{array}{l}\text { Head diam } \\
(\mathrm{nm})\end{array}$ & $\begin{array}{l}\text { Tail length } \\
(\mathrm{nm})\end{array}$ & $\begin{array}{l}\text { Tail width } \\
\text { (nm) }\end{array}$ & $\begin{array}{l}\text { Genome } \\
\text { length (bp) }\end{array}$ & GC (\%) & $\begin{array}{l}\text { Genomic } \\
\text { termini }\end{array}$ & No. of CDS & tRNA \\
\hline EcoSau & Siphoviridae & P335-like & $62 \pm 2$ & $179 \pm 6$ & $11 \pm 1$ & 31,703 & 48.4 & pac & 50 & No \\
\hline Ecolnf & Myoviridae & A novel type ${ }^{a}$ & $89 \pm 3$ & $202 \pm 4$ & $20 \pm 1$ & 106,071 & 38.2 & $\begin{array}{l}\text { Direct terminal } \\
\text { repeat ( } 817 \\
\text { bp) }\end{array}$ & 124 & Yes (2) \\
\hline
\end{tabular}

a Very distantly related to SPO1-like phages

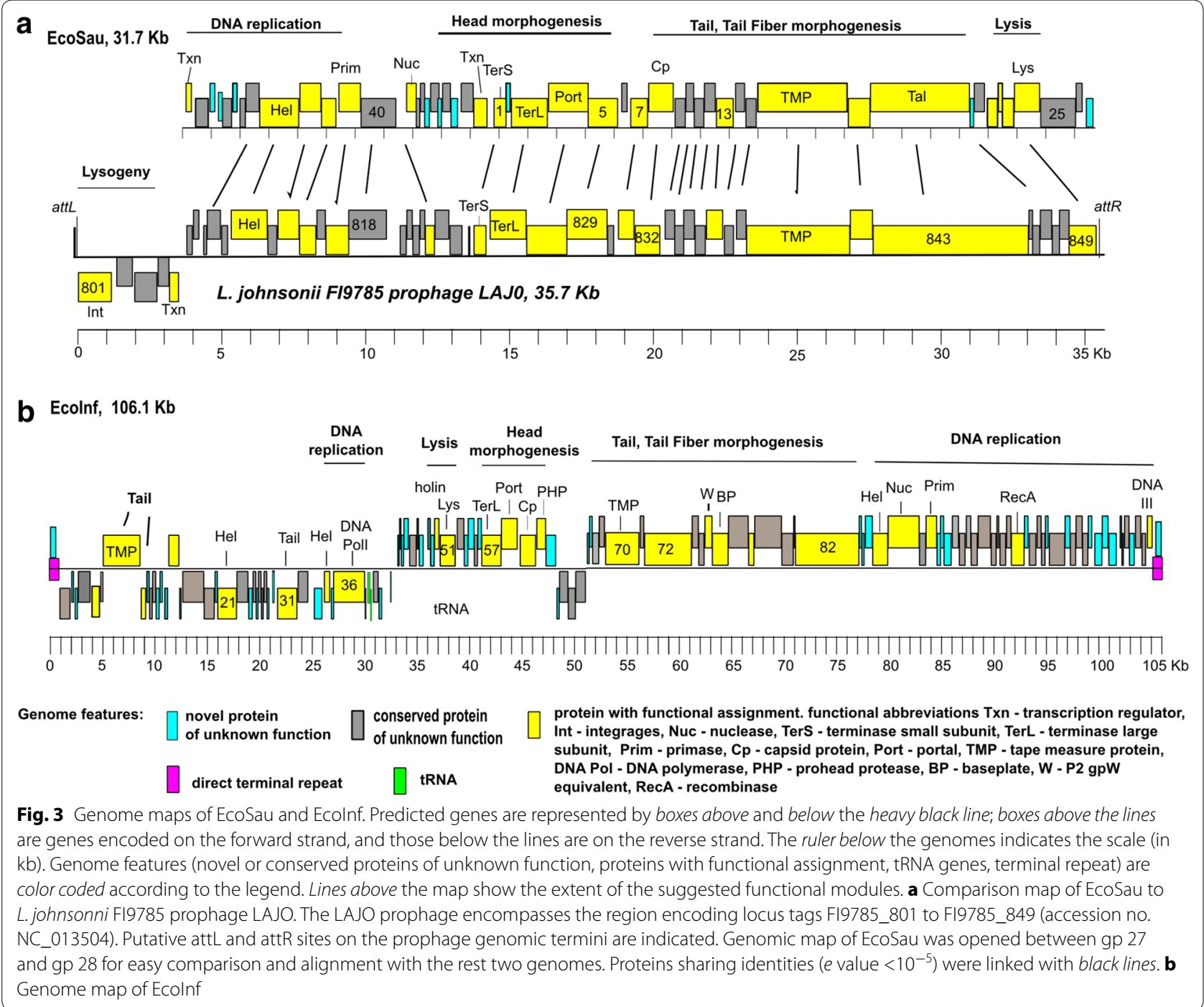

assembly, suggesting that the phage utilizes a pac type packaging mechanism [23]. The phages most similar to EcoSau, defined as having the most shared proteins, were members of the P335 group of phages, in particular Lactococcus phages TP901-1, Tuc2009, and P335 (Additional file 3: Table S3) [24, 25]. The shared genes were located primarily in the virion morphogenesis modules, and included terminase, scaffold, major and minor tail proteins. Conservation between EcoSau and prophage elements located in the genome entries of several LAB strains was also evident. The most similar of these to EcoSau was found to be a $35.7 \mathrm{~kb}$ prophage in the $L$. 
johnsonii FI9785 genome, with 25 EcoSau proteins exhibiting similarity $\left(e<10^{-5}\right)$ to FI9785 prophage proteins (Fig. 3; Additional file 3: Table S3). It is likely, however, that EcoSau is a virulent phage as the region of the EcoSau that would encode the lysogeny module is deleted. It should be noted that the P335 group of phages includes both temperate and virulent members [26].

The EcoInf genome consisted of 106,071 bp of unique sequence and was predicted to encode 124 proteins and two tRNAs (Fig. 3; Table 6). Functional annotations could not be made for 101 of the 124 EcoInf predicted proteins, as 52 exhibited similarity only to other proteins of unknown function and 49 had no recognizable homologs in the NCBI nr database. Despite the predominance of novel proteins, candidate genes involved in virion morphogenesis, DNA replication, and host cell lysis genes were identified. The lack of conservation between EcoInf and phage elements at a DNA and protein level suggests that EcoInf is a novel phage type. Phages most similar to EcoInf were of the SPO1-like group, with 41 out of 124 predicted EcoInf proteins sharing at least some level of protein sequence similarity (25-62\%), to proteins present in the genomes of SPO1-like phage group members, in particular Lactobacillus phage LP65 and Bacillus pumilus phage phiAGATE (Additional file 4: Table S4) [25, 27]. To date, the genomes of all large (>90 kb) myophages of Gram-positive bacteria in the Refseq database have characteristics common to a diverse group designated as SPO1-like, with the founding member being a paradigm phage of B. subtilis, SPO1 [27, 28]. However, the EcoInf genome is at least $15 \mathrm{~kb}$ smaller than any SPO1-like phage. The size difference was in part due to the genomic termini of EcoInf. The SPO1-like phages have direct terminal repeats, of at least $3 \mathrm{~kb}$ and usually 8-10 kb, encoding multiple proteins, whereas EcoInf has a terminal repeat of $817 \mathrm{bp}$, encoding a single protein. EcoInf, similar to SPO1-like phages in general, appears to be a virulent phage as no genes involved in prophage maintenance or lysogeny were identified.

\section{Phage effect in ethanol fermentation contaminated with $L$. fermentum}

Shaker-flask fermentation models simulating bacterial contamination during corn ethanol fermentation were established. In these tests, $250 \mathrm{ml}$ flask fermentations containing Saccharomyces cerevisiae growing on saccharified corn mash were incubated for $72 \mathrm{~h}$, either without added bacteria (infection-free control) or challenged with L. fermentum strain 0315-25 at an inoculation level of $10^{7}$ $\mathrm{cfu} / \mathrm{ml}$ (infection control). Some of the L. fermentumchallenged flasks were also treated with phage EcoInf and EcoSau, either singly or in combination. The effect of phage treatment on L. fermentum-contaminated fermentation was determined by measuring levels of residual glucose, lactic acid, acetic acid, as well as final ethanol yields of the fermentation systems. Cultures challenged with bacteria showed decreased ethanol yields, while phage-treated samples showed full recovery of ethanol production. At $72 \mathrm{~h}$, ethanol levels in the bacterial challenged systems without phage treatment (infection control) were $11.7 \%(\mathrm{w} / \mathrm{v})$, whereas the phage-treated systems attained yields of $\sim 13.5 \% \mathrm{w} / \mathrm{v}$, comparable to the infection-free control cultures (Fig. 4a). Residual glucose is an indicator of fermentation completeness; phage-treated and infection-free cultures contained similar residual glucose levels of $\sim 0.05 \%$, compared to $2.8 \%$ residual glucose in the infection control (Fig. 4b). Acid accumulation is indicative of infection by lactic acid bacteria. In systems challenged with bacteria but not treated, the levels of lactic and acetic acid were quite high, $0.53 \%$ $(\mathrm{w} / \mathrm{v})$ and $0.28 \%(\mathrm{w} / \mathrm{v})$, respectively. In contrast, lactic acid levels in the bacteria-free samples and in the phagetreated samples were lower, $0.19 \%(\mathrm{w} / \mathrm{v})$ to $0.24 \%(\mathrm{w} / \mathrm{v})$ (Fig. 4c). Similarly, acetic acid levels in the bacteria-free and phage-treated samples were approximately $0.08 \%$ w/v (Fig. 4d). These results indicate that all three phage treatments (EcoSau alone, EcoInf alone, and EcoSau and EcoInf combined) could restore the levels of ethanol, glucose, lactic acid, and acetic acid in the infected systems to those observed in the infection-free control. Compared to the inoculated phage levels at the start of the experiments $\left(10^{8}-10^{9} \mathrm{pfu} / \mathrm{ml}\right)$, the levels of recoverable phage decreased by approximately 100- to 1000-fold in the phage-treated corn mash systems by $24 \mathrm{~h}$ (Fig. 4e), possibly due to phage inactivation or adsorption to corn mash particles.

\section{Discussion}

The economics of the biofuel fermentation process precludes the level of sterility required to prevent bacterial contamination without the use of antibacterial agents. The potential for phage to be used to control LAB during fermentations has been speculated. The capacity for phage to control LAB is aided by the short time frame of fermentation (typically 50-60 h) and the batch nature of the process, both traits that limit the time and volume needed to be treated. However, the majority of phages have very narrow host ranges, limited to one or a few strains for a given species. Therefore, the prophylactic use of phage requires extensive knowledge of the target bacteria both in terms of diversity and abundance. Primarily culture-based enumeration methods have implicated LAB and Lactobacillus spp. in particular, as the dominant microbial contaminant during ethanol fermentation $[1,7,8]$. This is not unexpected given that LAB are well documented to dominate fermentation of many 


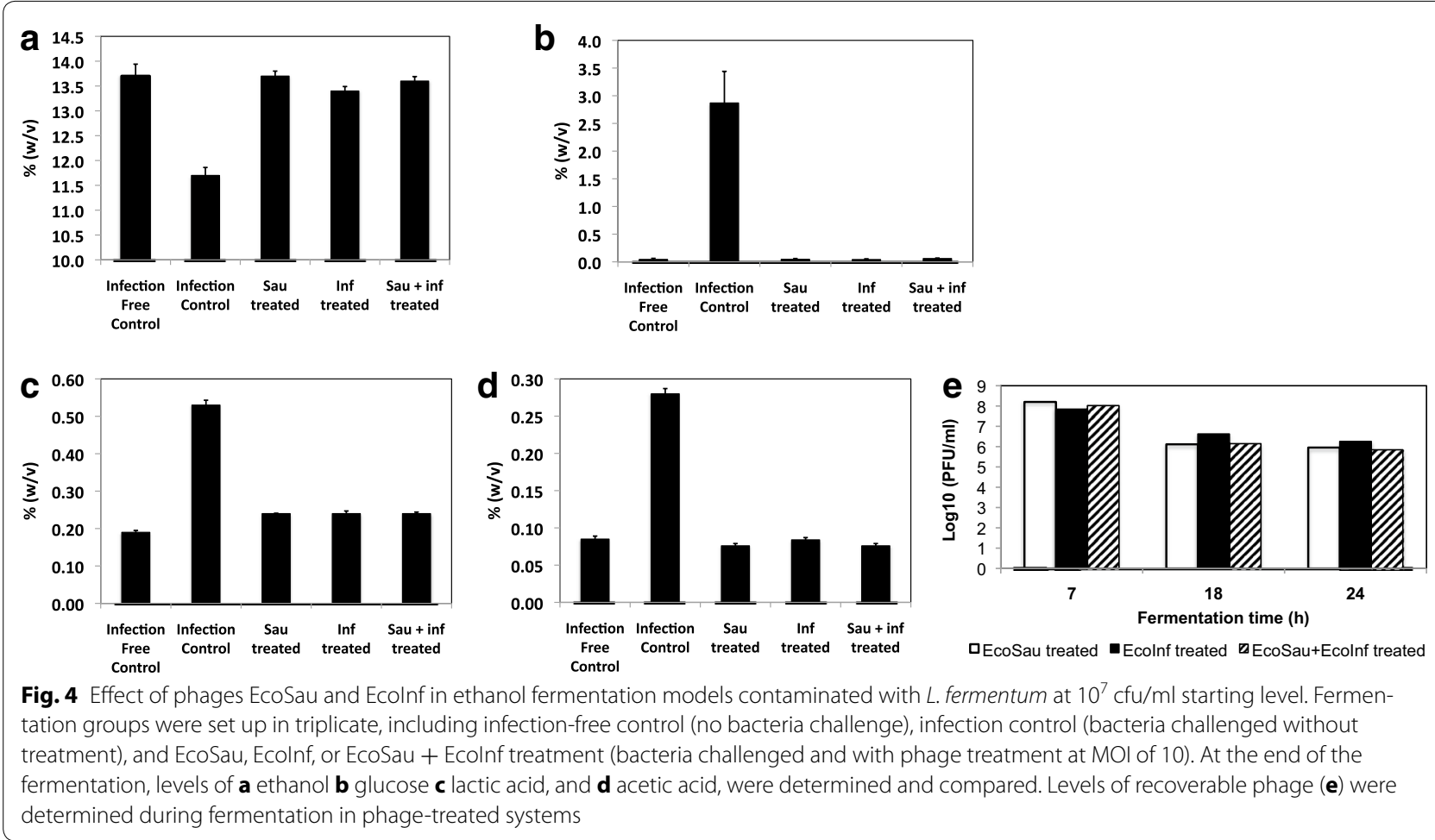

plant materials $[1,9]$. In this study, both culture-based and $16 \mathrm{~S}$ bacterial pyrosequencing analysis confirmed the total and relative abundance of $\mathrm{LAB}$, with $\mathrm{LAB}$ accounting for greater than $90 \%$ of the total population in the majority of the commercial fermentors tested. Lactobacillus species, including $L$. delbrueckii, $L$. fermentum, $L$. mucosae, and $L$. reuteri were the most well-represented species. In addition to Lactobacillus, other LAB genera including Lactococcus, Streptococcus, and Weissella were also identified. In this study, a range of $10^{3}-10^{7} \mathrm{cfu} / \mathrm{ml}$ contaminating bacteria was detected in fermentors of commercial ethanol plants. LAB levels reported here are consistent with previous work that reported LAB levels of $10^{5}-10^{8} \mathrm{cfu} / \mathrm{ml}$ in fermentors in the US and Brazil $[1,29]$. It should be noted that numerical abundance does not de facto implicate the capacity to cause fermentation slowdown. The correlation between the numerical dominance of other species or strains and their impact on fermentation loss is not clearly defined. Many members of these predominant species are capable of using obligately and/ or facultatively heterofermentative metabolism and produce a variety of end products including ethanol, lactic acid, acetic acid, $\mathrm{CO}_{2}$, and mannitol [30]. The metabolic traits of these lactic acid bacteria might make them more dangerous in inhibiting yeast fermentative activity compared to homofermentative lactic acid bacteria and nonacid producing bacteria, since lactic acid and acetic acid work synergistically in reducing the growth rate of yeast, decreasing its glucose consumption rate and ethanol production [2-5]. However, studies have demonstrated that even closely related LAB isolates exhibit differences in their capacity to inhibit yeast fermentation, indicating that fermentation slowdown is not entirely explained as a secondary effect of acid production $[5,8]$.

The two phages isolated and evaluated in this study, EcoSau and EcoInf, both exhibited broad host range, infecting the majority of L. fermentum stains isolated from multiple commercial plant corn mash samples. Even though some 230 Lactobacillus phages have been described, and genomic sequence data is available for over 20 of these, EcoSau and EcoInf were found to represent novel phage types, with only limited similarity to previously characterized phages [31]. EcoSau was found to be most similar to the Lactococcus P335-like phages, a group that includes closely related temperate and virulent isolates that interfere with dairy starter cultures $[24,25$, 32]. EcoInf was distantly related to the SPO1-like family of virulent phages, suggesting it is an authentic virulent phage. For bacterial control application purposes, it is important that the genome analysis indicates that both phage are virulent, that is neither phage possesses genes required for lysogenic control. Virulent phages are preferred over temperate phage for bacterial control applications, due to the potential for rapid resistance developing 
in the bacterial population as a result of prophage immunity to superinfection.

Application of EcoSau and EcoInf was shown to control corn mash contamination by L. fermentum strain 031525 , a strain previously demonstrated to cause aggressive fermentation slowdown [5, 8]. As discussed previously, not all $L$. fermentum isolates are equally effective in inhibiting yeast fermentation and thus L. fermentum 0315-25 was chosen to test phage control in corn mash. Inoculation of L. fermentum $0315-25$ at $10^{7} \mathrm{cfu} / \mathrm{ml}$ resulted in a $14 \%$ loss in ethanol yield. This ethanol yield loss is much greater compared to what is typically observed in commercial plants, which is $\sim 2 \%$ loss associated with chronic infection [33]. This bacterial challenge level caused the fermentation to be "stuck" at $\sim 48 \mathrm{~h}$, indicated by weight loss due to $\mathrm{CO}_{2}$ evolution (data not shown). The levels of lactic acid and acetic acid in this experiment were also high following bacterial challenge, enough to cause concern during daily operations as $0.2-0.8 \%(\mathrm{w} / \mathrm{v})$ lactic acid and $0.05-0.1 \%(\mathrm{w} / \mathrm{v})$ acetic acid are believed to be enough to stress yeast [2]. Challenging the systems with 10 -fold less L. fermentum $\left(10^{6} \mathrm{cfu} / \mathrm{ml}\right)$ resulted in less ethanol loss, and less alarming levels of lactic acid and acetic acid; however, phage treatment still restored fermentation parameters back to the levels found in the unchallenged sample (data not shown). For both levels of bacterial challenge, phage treatments mitigated the effects of L. fermentum challenge and restored the levels of ethanol, glucose, lactic acid, and acetic acid to those comparable to the infection-free control. Despite the potential for interference by polysaccharides or solids, here application of phage was shown to restore healthy fermentation characteristics in a corn mash matrix.

\section{Conclusions}

This study clearly demonstrates the predominance of lactic acid bacteria, notably Lactobacillus spp., in the bacterial contamination flora of commercial ethanol fermentations. Adding phages EcoSau and EcoInf to $L$. fermentum-contaminated yeast fermentation models resulted in reductions in organic acid levels and restoration of ethanol yields. These fermentation experiments demonstrate that phage efficacy is observed in a corn mash matrix, and support a model in which phage cocktails with broad coverage of major lactic acid bacteria species can be applied directly to corn mash, potentially as antibiotic alternatives in the ethanol fermentation industry.

\section{Methods}

\section{Bacterial and phage culture conditions}

Bacterial strains were routinely cultured at $30{ }^{\circ} \mathrm{C}$ using deMan-Rogosa-Sharpe medium (BD Difco,
Becton-Dickinson, Sparks, MD, USA) in a hypoxia chamber under controlled gas composition $\left(5.1 \% \mathrm{CO}_{2}\right.$, $\left.5.1 \% \mathrm{H}_{2}, 89.8 \% \mathrm{~N}_{2}\right)$. MRS agar plates contained $1.5 \%$ $(\mathrm{w} / \mathrm{v})$ agar (BD Difco). Phage were titered and propagated using the soft agar overlay method [34] on MRS bottom plates and using MRS soft agar [MRS broth plus $0.5 \%$ agar (Bacto) and $20 \mathrm{mM} \mathrm{CaCl}_{2}$ ]. Due to acid production during bacterial growth, the $\mathrm{pH}$ of the phage stocks were adjusted to pH 6.5 with $\mathrm{NaOH}$.

\section{Bacterial diversity analysis of mash samples}

Corn mash samples were collected from ethanol plant fermentors at different fermentation stages and cold shipped overnight to our laboratory. For bacterial diversity analysis, total DNA was isolated from each sample using Mo Bio UltraClean ${ }^{\text {TM }}$ Microbial DNA Isolation kit (Mo Bio Laboratories, CA, USA). DNA was subject to bacterial tag-encoded FLX amplicon pyrosequencing (bTEFAP) using primers 939F-TTGACGGGGGCCCGCAC and 1492R-TACCTTGTTACGACTT, and resulting sequences were analyzed as previously described [35, 36]. All sequences passing the quality score were compared to a ribosomal database using BLASTn to make taxonomic classifications [37].

\section{Microbial analysis and bacterial strain isolation from mash samples}

Corn mash samples were collected from fermentors of commercial ethanol plants and shipped immediately to the laboratory on ice packs. Analysis of the mash samples were carried out immediately upon sample reception, which is within $20-24 \mathrm{~h}$ since sampling from plants. Yeast counts were determined by plating the serial diluted samples onto potato dextrose agar (BD BBL ${ }^{\mathrm{TM}}$, Franklin Lakes, NJ, USA) and incubating at $30{ }^{\circ} \mathrm{C}$ for $1-2$ days. The identity of yeast colonies on the plates was confirmed morphologically by examination under a microscope. Total bacterial counts were determined by serial dilution, plating on MRS agar plates supplemented with $0.05 \mathrm{mg} / \mathrm{ml}$ cycloheximide, and incubating in a hypoxic chamber at $30{ }^{\circ} \mathrm{C}$ for $1-3$ days. From the highest dilution plates, representative bacterial colonies from the predominant colony morphological types were subject to several rounds of sequential colony purification. Resulting isolates were identified via colony PCR for $16 \mathrm{~S}$ rDNA gene sequencing, using primers 16S.F-CCTACGGGAGGCAGCAG, and 16S.R-CCCCGTCAATTCCTTTGAGTTT. Strains isolated from this study and from previous work $[5,8]$ were used for phage isolation and characterization.

\section{Phage isolation and host-range characterization}

Phages EcoSau and EcoInf were isolated from commercial sauerkraut and municipal wastewater influent, 
respectively, using a previously described enrichment method [38]. Briefly, enrichments were set up with $25 \mathrm{ml}$ of filter-sterilized sample liquids and $25 \mathrm{ml}$ double-strength MRS broth to which $1 \mathrm{ml}$ of an overnight $L$. fermentum $0315-25$ culture $\left(\sim \mathrm{OD}_{600}=10\right)$ was added. Following $24 \mathrm{~h}$ incubation at $30{ }^{\circ} \mathrm{C}$, bacteria were removed by centrifugation $(10,000 \times g, 5 \mathrm{~min})$ and passage through $0.22 \mu \mathrm{m}$ filters. Phage host-range determinations were made using a routine test dilution (RTD) assay, with the RTD defined as the last 10-fold serial dilution that produced confluent clearing when spotted onto a lawn of the phage host. The RTD concentrations determined for EcoSau and EcoInf were both $\sim 10^{5} \mathrm{pfu} / \mathrm{ml}$. Ten microliters of the phages diluted RTD were spotted onto lawns of individual hosts. The spotted plates were incubated at $30{ }^{\circ} \mathrm{C}$ for 24-48 $\mathrm{h}$ before they were scored for the appearance of clearing, which were interpreted as positive host-range results.

\section{TEM}

Phage lysates were prepared for transmission electron microscopy (TEM) by diluting lysates 1:5 with TEM buffer $(20 \mathrm{mM} \mathrm{NaCl}, 10 \mathrm{mM}$ Tris- $\mathrm{HCl} \mathrm{pH} \mathrm{7.5,} 2 \mathrm{mM}$ $\mathrm{MgSO}_{4}$ ) before applying to $10-15 \mathrm{~nm}$ carbon films using the Valentine method [39]. Specimens were stained with $2 \%(\mathrm{w} / \mathrm{v})$ aqueous uranyl acetate and observed on a JEOL 1200EX transmission electron microscope operating at an acceleration voltage of $100 \mathrm{kV}$. Measurements were calibrated using a carbon grating replica (Electron Microscopy Sciences, Hatfield, PA, USA).

\section{Phage genome sequencing and annotation}

Filter-sterilized phage plate lysates were used for phage genomic DNA preparation with the Wizard DNA cleanup kit (Promega, Madison, WI, USA) following the protocols described previously [40]. Phages were sequenced to 23 -fold coverage by 454 pyrosequencing (Roche/454 Life Sciences, Branford, CT, USA). Gap closure was completed by amplification of gap regions by PCR followed by Sanger sequencing of the products. The sequences and structure of the genome ends were determined as previously described [40]. Finished DNA sequences were analyzed by Genemark.hmm [41] to detect protein-coding genes. The predicted coding regions were manually edited in Artemis [42]. Predicted proteins were searched against the GenBank nr database using BLASTp [43]. Protein conserved domains were detected with InterProScan version 4.7 run locally [44]. Transmembrane domains and signal sequences were predicted using TMHMM 2.0 (http://www.cbs.dtu.dk/services/ TMHMM) and SignalP 3.0 (http://www.cbs.dtu.dk/ services/SignalP-3.0/) [45]. Prediction of tRNA genes were carried out using tRNAscan (http://lowelab.ucsc. edu/tRNAscan-SE/) [46]. Phage genome maps were rendered with DNA Master (http://cobamide2.bio. pitt.edu/computer.htm).

\section{Nucleotide sequence accession number}

The genome sequences of phages EcoSau and EcoInf have been deposited in the GenBank database under accession numbers KP027015 (vB_LfeS_EcoSau) and KP054477 (vB_LfeM_EcoInf).

\section{Ethanol fermentation and phage efficacy testing}

Ethanol fermentations were performed in shake flasks as described previously [8]. Corn mash (approximately $33 \%$ solids) was obtained from a commercial dry-grind ethanol facility and stored at $-20{ }^{\circ} \mathrm{C}$ prior to use. Corn mash $(40 \mathrm{ml})$ was dispensed in $50 \mathrm{ml}$ Erlenmeyer flasks, and supplemented with ammonium sulfate $(0.12 \% \mathrm{w} / \mathrm{v})$ and glucoamylase $(20 \mu \mathrm{l}$ Optidex L-400, Genencor International Inc., Rochester NY, USA). Each flask was inoculated with S. cerevisiae strain NRRL Y-2034 (obtained from the ARS Culture Collection maintained at the USDA-ARS National Center for Agricultural Utilization Research, Peoria, IL, USA) to an initial density of $10^{7} \mathrm{cfu} /$ $\mathrm{ml}$. When indicated, infected samples were inoculated with L. fermentum 0315-25 to $10^{7} \mathrm{cfu} / \mathrm{ml}$. Phage-treated samples received either phage EcoInf, phage EcoSau, or the combination of two (1:1 ratio) at a treatment MOI of 10 (10 phage particles per bacterial cell). All groups (infection-free control, infection control, and phagetreated groups) were set up in triplicate and were incubated at $32{ }^{\circ} \mathrm{C}$ with shaking (100 rpm) for $72 \mathrm{~h}$. Phage levels in phage-treated groups were determined during fermentation $(7,18$, and $24 \mathrm{~h})$. To be specific, $1.5 \mathrm{ml}$ fermentation sample was aseptically taken and centrifuged. The supernatant was filtered through a $0.45 \mu \mathrm{m}$ filter and the serial dilutions of the filtered sample were plated on the pre-made host lawn. Concentrations of ethanol, glucose, lactic acid, and acetic acid at $72 \mathrm{~h}$ were determined by high performance liquid chromatography using a 300 mm Aminex HPX 87H column (Bio-Rad Laboratories, Inc., Hercules, CA, USA) on a HP 1100 Series HPLC system equipped with a refractive index detector (Agilent Technologies, Santa Clara, CA, USA). Samples $(10 \mu \mathrm{l})$ were injected onto a heated column $\left(65{ }^{\circ} \mathrm{C}\right)$ and eluted at $0.6 \mathrm{ml} / \mathrm{min}$ using $5 \mathrm{mM} \mathrm{H}_{2} \mathrm{SO}_{4}$ as mobile phase. Data were reported as the mean value \pm standard deviation of triplicate cultures. 


\section{Additional files}

Additional file 1: Table S1. Predicted proteins, gene starts and annotations of phage EcoSau.

Additional file 2: Table S2. Predicted proteins, gene starts and annotations of phage Ecolnf.

Additional file 3: Table S3. Relationship of EcoSau to other phages and prophage elements.

Additional file 4: Table S4. Relationship of phage Ecolnf to SPO1-like phages.

\section{Abbreviations}

LAB: lactic acid bacteria; OUT: operational taxonomic units; cfu: colony forming units; MRS: deMan-Rogosa-Sharpe; TEM: transmission electron microscopy; RTD: routine test dilution; MOI: multiplicity of infection; HPLC: high performance liquid chromatography; BLAST: Basic Local Alignment Search Tool; NCBI: National Center of Biotechnology Information; SRB: sulfate reducing bacteria.

\section{Authors' contributions}

$\mathrm{ML}$ and EJS designed and conducted the study, analyzed the data, and cowrote the manuscript. KMB designed and conducted the ethanol fermentation tests, and analyzed the fermentation data. JJG generated the TEM images. JJG, JDB and RY assisted in genome sequencing and annotation, and writing of the manuscript. MDM assisted in microbiological analysis. All authors read and approved the final manuscript.

\section{Author details}

${ }^{1}$ Ecolyse Inc., 11142 Hopes Creek Rd., College Station, TX 77845, USA. ${ }^{2}$ Renewable Product Technology Research Unit, National Center for Agricultural Utilization Research, Agricultural Research Service, U.S. Department of Agriculture, 1815 N. University St., Peoria, IL 61604, USA. ${ }^{3}$ Center for Phage Technology, 2128 TAMU, Texas A\&M University, College Station, TX 77843, USA. ${ }^{4}$ Department of Animal Science, 2471 TAMU, Texas A\&M University, College Station, TX 77843, USA. ${ }^{5}$ Department of Biochemistry and Biophysics, 2128 TAMU, Texas A\&M University, College Station, TX 77843, USA.

\section{Acknowledgements}

This work was funded by NSF SBIR Grant No. 1230441 and Texas A\&M and Texas A\&M AgriLife Research. We thank the staff at various commercial ethanol plants, especially Dan Matlick at Lincolnway Energy (Nevada, IA) and Sivaraj Chokkaram at Green Plains Holdings II LLC (Riga, Ml), for providing corn mash fermentation samples and valuable discussion on contamination controls.

\section{Compliance with ethical guidelines}

\section{Competing interests}

The authors declare that they have no competing interests.

Received: 9 February 2015 Accepted: 25 August 2015

Published online: 04 September 2015

\section{References}

1. Skinner KA, Leathers TD (2004) Bacterial contaminants of fuel ethanol production. J Ind Microbiol Biotechnol 31(9):401-408

2. Narendranath NV, Thomas KC, Ingledew WM (2001) Effects of acetic acid and lactic acid on the growth of Saccharomyces cerevisiae in a minimal medium. J Ind Microbiol Biotechnol 26(3):171-177

3. Graves T, Narendranath NV, Dawson K, Power R (2007) Interaction effects of lactic acid and acetic acid at different temperatures on ethanol production by Saccharomyces cerevisiae in corn mash. Appl Microbiol Biotechnol 73(5):1190-1196

4. Narendranath NV, Power R (2005) Relationship between $\mathrm{pH}$ and medium dissolved solids in terms of growth and metabolism of lactobacilli and
Saccharomyces cerevisiae during ethanol production. Appl Environ Microbiol 71(5):2239-2243

5. Bischoff KM, Liu S, Leathers TD, Worthington RE, Rich JO (2009) Modeling bacterial contamination of fuel ethanol fermentation. Biotechnol Bioeng 103(1):117-122

6. Summer EJ, Liu M, Gill JJ, Grant M, Chan-Cortes TN, Ferguson L, Janes C, Lange K, Bertoli M, Moore C et al (2011) Genomic and functional analysis of Rhodococcus equi phages ReqiPepy6, ReqiPoco6, ReqiPine5 and ReqiDocB7. Appl Environ Microbiol 77(2):669-683

7. Schell DJ, Dowe N, Ibsen KN, Riley CJ, Ruth MF, Lumpkin RE (2007) Contaminant occurrence, identification and control in a pilot-scale corn fiber to ethanol conversion process. Bioresour Technol 98(15):2942-2948

8. Bischoff KM, Skinner-Nemec KA, Leathers TD (2007) Antimicrobial susceptibility of Lactobacillus species isolated from commercial ethanol plants. J Ind Microbiol Biotechnol 34(11):739-744

9. Lucena BT, dos Santos BM, Moreira JL, Moreira AP, Nunes AC, Azevedo V, Miyoshi A, Thompson FL, de Morais MA Jr (2010) Diversity of lactic acid bacteria of the bioethanol process. BMC Microbiol 10:298

10. Garneau JE, Moineau S (2011) Bacteriophages of lactic acid bacteria and their impact on milk fermentations. Microb Cell Fact 10(Suppl 1):S20

11. Brussow H (2001) Phages of dairy bacteria. Annu Rev Microbiol 55:283-303

12. Brussow H, Hendrix RW (2002) Phage genomics: small is beautiful. Cell 108(1):13-16

13. Ackermann HW (2007) 5500 Phages examined in the electron microscope. Arch Virol 152(2):227-243

14. Quiberoni A, Moineau S, Rousseau GM, Reinheimer JA, Ackermann HW (2010) Streptococcus thermophilus bacteriophages. Int Dairy J 20:657-664

15. Summer E, Liu M, Summer N, Gill J, Janes C, Young R (2011) Phage of sulfate reducing bacteria isolated from high saline environment. In: Proceedings of CORROSION 2011. NACE International 2011, Houston, TX, paper 11222

16. Summer NS, Summer EJ, Gill JJ, Young R (2008) Phage remediation of microbe-induced corrosion. In: Proceedings of CORROSION 2008. NACE International 2008, Los Vegas, NV, paper 3343

17. Summer EJ, Enderle CJ, Ahern SJ, Gill JJ, Torres CP, Appel DN, Black MC, Young R, Gonzalez CF (2010) Genomic and biological analysis of phage Xfas53 and related prophages of Xylella fastidiosa. J Bacteriol 192(1):179-190

18. Carmody LA, Gill JJ, Summer EJ, Sajjan US, Gonzalez CF, Young RF, LiPuma JJ (2010) Efficacy of bacteriophage therapy in a model of Burkholderia cenocepacia pulmonary infection. J Infect Dis 201(2):264-271

19. Bertozzi Silva J, Sauvageau D (2014) Bacteriophages as antimicrobial agents against bacterial contaminants in yeast fermentation processes. Biotechnol Biofuels 7(1):123

20. Roach DR, Khatibi PA, Bischoff KM, Hughes SR, Donovan DM (2013) Bacteriophage-encoded lytic enzymes control growth of contaminating Lactobacillus found in fuel ethanol fermentations. Biotechnol Biofuels 6(1):20

21. Khatibi PA, Roach DR, Donovan DM, Hughes SR, Bischoff KM (2014) Saccharomyces cerevisiae expressing bacteriophage endolysins reduce Lactobacillus contamination during fermentation. Biotechnol Biofuels 7:104

22. Klumpp J, Dorscht J, Lurz R, Bielmann R, Wieland M, Zimmer M, Calendar $\mathrm{R}$, Loessner MJ (2008) The terminally redundant, nonpermuted genome of Listeria bacteriophage A511: a model for the SPO1-like myoviruses of gram-positive bacteria. J Bacteriol 190(17):5753-5765

23. Casjens SR, Gilcrease EB (2009) Determining DNA packaging strategy by analysis of the termini of the chromosomes in tailed-bacteriophage virions. Methods Mol Biol 502:91-111

24. Kelly WJ, Altermann E, Lambie SC, Leahy SC (2013) Interaction between the genomes of Lactococcus lactis and phages of the P335 species. Front Microbiol 4:257

25. Deveau H, Labrie SJ, Chopin MC, Moineau S (2006) Biodiversity and classification of lactococcal phages. Appl Environ Microbiol 72(6):4338-4346

26. Mahony J, Martel B, Tremblay DM, Neve H, Heller KJ, Moineau S, van Sinderen D (2013) Identification of a new P335 subgroup through molecular analysis of lactococcal phages Q33 and BM13. Appl Environ Microbiol 79(14):4401-4409 
27. Klumpp J, Lavigne R, Loessner MJ, Ackermann HW (2010) The SPO1related bacteriophages. Arch Virol 155(10):1547-1561

28. Stewart CR, Casjens SR, Cresawn SG, Houtz JM, Smith AL, Ford ME, Peebles CL, Hatfull GF, Hendrix RW, Huang WM et al (2009) The genome of Bacillus subtilis bacteriophage SPO1. J Mol Biol 388(1):48-70

29. Lucena BT, Dos Santos BM, Moreira JL, Moreira AP, Nunes AC, Azevedo V, Miyoshi A, Thompson FL, de Morais MAJ (2010) Diversity of lactic acid bacteria of the bioethanol process. BMC Microbiol 10(1):298

30. Stiles ME, Holzapfel WH (1997) Lactic acid bacteria of foods and their current taxonomy. Int J Food Microbiol 36(1):1-29

31. Villion M, Moineau S (2009) Bacteriophages of lactobacillus. Front Biosci 14:1661-1683

32. Labrie SJ, Josephsen J, Neve H, Vogensen FK, Moineau S (2008) Morphology, genome sequence, and structural proteome of type phage P335 from Lactococcus lactis. Appl Environ Microbiol 74(15):4636-4644

33. Connolly C (1999) Bacterial contaminants and their effects on alcohol production. In: Jacques K, Lyons TP, Kelsall DR (eds) The alcohol textbook, 3rd edn. Nottingham University Press, Nottingham, pp 317-334

34. Adams MH (1959) Bacteriophages. Interscience Publishers, New York

35. Williams WL, Tedeschi LO, Kononoff PJ, Callaway TR, Dowd SE, Karges K, Gibson ML (2010) Evaluation of in vitro gas production and rumen bacterial populations fermenting corn milling (co)products. J Dairy Sci 93(10):4735-4743

36. Dowd SE, Callaway TR, Wolcott RD, Sun Y, McKeehan T, Hagevoort RG, Edrington TS (2008) Evaluation of the bacterial diversity in the feces of cattle using 16S rDNA bacterial tag-encoded FLX amplicon pyrosequencing (bTEFAP). BMC Microbiol 8:125
37. Altschul SF, Madden TL, Schaffer AA, Zhang J, Zhang Z, Miller W, Lipman DJ (1997) Gapped BLAST and PSI-BLAST: a new generation of protein database search programs. Nucleic Acids Res 25(17):3389-3402

38. Summer EJ, Gonzalez CF, Bomer M, Carlile T, Embry A, Kucherka AM, Lee J, Mebane L, Morrison WC, Mark L et al (2006) Divergence and mosaicism among virulent soil phages of the Burkholderia cepacia complex. J Bacteriol 188(1):255-268

39. Valentine RC, Shapiro BM, Stadtman ER (1968) Regulation of glutamine synthetase. XII. Electron microscopy of the enzyme from Escherichia coli. Biochemistry 7(6):2143-2152

40. Summer EJ (2009) Preparation of a phage DNA fragment library for whole genome shotgun sequencing. Methods Mol Biol 502:27-46

41. Lukashin AV, Borodovsky M (1998) GeneMark.hmm: new solutions for gene finding. Nucleic Acids Res 26(4):1107-1115

42. Rutherford K, Parkhill J, Crook J, Horsnell T, Rice P, Rajandream MA, Barrell B (2000) Artemis: sequence visualization and annotation. Bioinformatics 16(10):944-945

43. Camacho C, Coulouris G, Avagyan V, Ma N, Papadopoulos J, Bealer K, Madden TL (2009) BLAST+: architecture and applications. BMC Bioinformatics 10:421

44. Hunter S, Apweiler R, Attwood TK, Bairoch A, Bateman A, Binns D, Bork P, Das U, Daugherty L, Duquenne L et al (2009) InterPro: the integrative protein signature database. Nucleic Acids Res 37(Database issue):D211-D215

45. Bendtsen JD, Nielsen H, von Heijne G, Brunak S (2004) Improved prediction of signal peptides: SignalP 3.0. J Mol Biol 340(4):783-795

46. Schattner P, Brooks AN, Lowe TM (2005) The tRNAscan-SE, snoscan and snoGPS web servers for the detection of tRNAs and snoRNAs. Nucleic Acids Res Web Server issue:W686-W689

\section{Submit your next manuscript to BioMed Central and take full advantage of:}

- Convenient online submission

- Thorough peer review

- No space constraints or color figure charges

- Immediate publication on acceptance

- Inclusion in PubMed, CAS, Scopus and Google Scholar

- Research which is freely available for redistribution

Submit your manuscript at

www.biomedcentral.com/submit

C Biomed Central 